І.С. Зозуля, А.О. Волосовець, А.І. Зозуля, І.Ю. Бігун

Національна медична академія післядипломної освіти імені П.Л. Шупика, кафедра медицини невідкладних станів (Київ)

\title{
Невідкладна допомога та ведення пацієнтів із запамороченням
}

\section{Вступ}

Запаморочення несистемного характеру - одна з найчастіших скарг на прийомі у лікарів різних медичних спеціальностей. Хоча запаморочення вважають доброякісним станом, який піддається лікуванню, існують деякі його види, які становлять загрозу для життя пацієнта. Ізольоване системне запаморочення інколи може бути ознакою маніфестації дисфункції периферичного вестибулярного апарату або патології внутрішнього вуха. Наприклад, гостре системне запаморочення на тлі інфекції верхніх дихальних шляхів вважають доброякісним симптомом, і пацієнтів лікують консервативно, якщо не виникає симптомів двоїння, гіпестезії періоральної ділянки, атаксії чи слабкості в кінцівках.

При скаргах на диплопію та інші стовбурові симптоми необхідна термінова медична допомога і дообстеження з метою виключення інфаркту стовбура мозку або мозочка. У цьому разі проводять комп'ютерну томографію або магнітно-резонансну томографію головного мозку.

Діагностика патологічного процесу в центральній нервовій системі ґрунтується на даних анамнезу, супутніх скаргах і ознаках ураження структур задньої черепної ямки: патологічний ністагм, атаксія, слабкість, падіння хворого в бік напрямку ністагму. Несистемне запаморочення пацієнти часто описують як нестійкість, хиткість ходи. Несистемне запаморочення може бути симптомом різних патологічних станів, починаючи від периферичної вестибулопатії (при ураженні внутрішнього вуха) до постуральної гіпотензії, порушення ритму серця, впливу лікарських або токсичних речовин і органічних уражень нервової системи.

Основні причини системного і несистемного запаморочення - ураження вуха чи периферичного вестибулярного апарату, ураження центральної нервової системи, дія фармакологічних препаратів і наявність системних захворювань (ішемія чи інфаркт стовбура мозку, базилярна мігрень, епілептичні напади, розсіяний склероз, мальформація Арнольда - Кіарі та ін.).

Системне запаморочення - галюцинація руху. Зазвичай це пов'язано з ураженням периферичного вестибулярного апарату, тобто внутрішнього вуха чи лабіринта. При ураженні внутрішнього вуха і завитка відзначають запаморочення на фоні втрати або зниження слуху (як при хворобі Мен'єра).

Відчуття стійкості постави і можливість підтримання бажаної пози залежить від трьох основних систем: внутрішнього вуха, зорового аналізатора і периферичних нервових волокон - провідників пропріоцептивних імпульсів. Слух також має важливе значення у підтримці рівноваги та орієнтації в просторі. Вся отримана сенсорна інформація проходить обробку в головному мозку і координується мозочком та руховими провідниковими структурами центральної нервової системи для прийняття певного положення тіла у спокої та під час руху.

Запаморочення - одна з найпоширеніших скарг серед пацієнтів будь-якого віку, особливо похилого. Справжнє запаморочення - це галюцинація руху людей або предметів навколо людини, або людини навколо предметів. Під запамороченням пацієнти розуміють різні відчуття: «дурноти», слабкості, потемніння в очах, які можуть виникати під час ортостатичної гіпотензії, гіпоглікемії, синдрому слабкості синусового вузла (при серцево-судиннихзахворюваннях, аортальному стенозі). Нестійкість постави пацієнти можуть відзначати як при ураженні мозочка, так і при периферичній нейропатії, спричиненій цукровим діабетом або захворюванням спинного мозку. Інколи хворі відзначають такі симптоми, як тяжкість, сп'яніння. При депресії, фобії, тривозі може виникати психогенне запаморочення.

\section{Класифікація запаморочень}

Запаморочення поділяють на:

- вестибулярне (істинне, вертиго, системне), пов'язане з вестибулярним апаратом;

- несистемне (невестибулярне), що виникає за межами вестибулярного апарату.

У свою чергу вестибулярне запаморочення розподіляють на:

- периферичне (ураження лабіринту);

- проміжне (виникає у вестибулярному нерві);

- центральне (виникає у центральній нервовій системі). Найчастіші причини центрального запаморочення:

- судинні порушення (гостра ішемія в ділянці стовбура мозку інсульт, транзиторна ішемічна атака);

- вертебробазилярна недостатність;

- хронічне порушення мозкового кровообігу;

- цервікальний спондиліт;

- остеохондроз;

- хлистова травма шиї;

- травми та пухлини головного мозку

Із найпоширеніших причин периферичного запаморочення доброякісне пароксизмальне позиційне запаморочення, хвороба Мен'єра, вестибулярна мігрень, лабіринтит, травми голови (перелом пірамідки скроневої кістки) і хірургічні травми, фістула лабіринту.

Як свідчить практика, артеріальна гіпертензія як така не є причиною запаморочень. Найчастіша причина системного (вестибулярного) запаморочення у пацієнтів з артеріальною гіпертензією - доброякісне пароксизмальне позиційне запаморочення, несистемного - психомоторне запаморочення. 3 інших причин запаморочення при артеріальній гіпертензії - надмірне чи надто швидке зниження артеріального тиску, гіпоглікемія (при цукровому діабеті), порушення ритму і провідності серця, ортостатична реакція (у людей похилого віку, при цукровому діабеті).

\section{Периферичне вестибулярне запаморочення}

Периферичне вестибулярне запаморочення включає доброякісне позиційне запаморочення, вестибулярний нейроніт (хворобу Мен'єра). Інколи причиною може бути здавлення судиною. Цей стан характеризується нападами системного запаморочення при зміні положення голови. Частота цих запаморочень зростає з віком: близько $40 \%$ людей віком $\geqslant 70$ років хоча б один раз відчували таке запаморочення. Ця форма запаморочення має доброякісний перебіг, проте у деяких людей напади можуть повторюватися і навіть призвести до інвалідизації. Можливі спонтанний ністагм; падіння у бік, протилежний напрямку ністагму; нудота, блювання.

Діагноз лабіринтиту має такі варіації: вестибулярний нейроніт, ідіопатичний лабіринтит, вірусний лабіринтит. Вестибулярний нейроніт характеризується одиночними або повторювальними епізодами істинного системного запаморочення, які можуть продовжуватися від декількох годин до декількох днів і часто супроводжуються блюванням на початку нападу. При додатковому зниженні слуху можна думати про ураження всього слухового лабіринту (лабіринтит). Вираженість запаморочення може зменшуватися при рухах голови. Прогноз сприятливий.

Лікування включає застосування антагоністу $\mathrm{H}_{3}$-гістамінових рецепторів бетагістину, який вибірково покращує кровотік, посилює мікроциркуляцію і нормалізує стан ендолімфи у внутрішньому вусі. Діючи центрально на вестибулярні ядра стовбура мозку, препарат нормалізує імпульсацію з периферичних рецепторів. Бетагістин не впливає на артеріальний тиск. Добова доза 
препарату - 8; 16; 32 та 48 мг. Можна застосовувати антигістамінні препарати (меклозин у добовій дозі 50 мг). Враховуючи його снодійний ефект, рекомендують починати лікування з 12,5 мг 3 рази на добу, поступово підвищуючи дозу. Підшкірне введення скополаміну зменшує вираженість нудоти іблювання. Ускладненням $€$ зниження акомодації, сухість у роті.

\section{Хвороба Мен'єра}

Зазвичай починається увіці 30-50 років і невпинно прогресує. Характеризується нападами сильного запаморочення, що супроводжується блюванням, шумом у вусі, зниженням слуху, відчуттям тяжкості та стиснення у вусі. Напад запаморочення може тривати від декількох днів до тижнів. Запаморочення буває настільки сильним, що хворий може падати. Свідомість не порушується, але може спостерігатися відчуття нереальності. У >50\% випадків при хворобі Мен'єра однобічний процес стає двобічним і формується стабільний дефект.

Лікування - див. вище. У ряду випадків медикаментозна терапія не допомагає, тоді застосовують хірургічне лікування - лабіринтектомію чи пересічення вестибулярного нерва. Медикаментозну деструкцію лабіринту проводять за допомогою аміноглікозидів - препаратів, що руйнують вестибулярні волоскові клітини у внутрішньому вусі. У цих випадках застосовують гентаміцин, який вводять через прокол у барабанній перетинці. Слух при цьому не порушується.

Надання допомоги:

- ендолімфатичне шунтування внутрішнього вуха із соскоподібним відростком;

- селективне пересічення вестибулярного нерва в задній черепній ямці може зберегти пацієнту слух.

\section{Токсичне ураження вестибулярного аналізатора}

Токсичне ураження вестибулярного аналізатора можливе при застосуванні ототоксичних антибіотиків, особливо гентаміцину. При цьому відзначають двобічне ураження вестибулярної функції. У хворого виявляють виражене порушення координації (атаксія) і таке порушення зору, як нестійке зображення (осцилопія). Зазвичай повної загибелі вестибулярних волокон не відбувається, тому можна сподіватися на деяке відновлення функції.

\section{Фістула перилімфи}

Фістула перилімфи - розрив перетинки між рідинною ділянкою напівколового каналу і середнім вухом, що відзначають при травмі вуха. У пацієнтів відбуваються напади запаморочення і атаксії, що поєднується з підвищенням тиску у вусі. У деяких хворих симптоми швидко наростають, у деяких фістули закриваються.

Надання допомоги:

- ліжковий режим протягом >2 тиж;

- оперативне лікування - хірургічне закриття фістули м'язовою тканиною.

\section{Пухлина присінково-завиткового нерва}

Пухлина присінково-завиткового нерва (VIII пара черепних нервів), тобто пухлина мосто-мозочкового кута, розвивається зі шваннівських клітин (шванноми). Очевидно, вони є похідними з вестибулярної ділянки нерва в слуховому каналі. Ці пухлини швидко ростуть і стискають оточуючі нервові утвори (слуховий, лицевий, трійчастий нерви, а в деяких випадках - і стовбур мозку та мозочок). У пацієнтів відзначають нестійке запаморочення (20\%), порушення рівноваги (50\%). Інколи такі пухлини призводять до втрати слуху і рівноваги, а також ураження лицевого нерва (периферичного характеру) і здавлення стовбура мозку.

Надання допомоги:

- хірургічне лікування (нейрохірург, оториноларинголог);

- моніторинг функції VII та VIII пар черепних нервів у ході оперативного лікування дає можливість зберегти їх функцію.

\section{Центральне вестибулярне запаморочення}

Центральне вестибулярне запаморочення зумовлено ураженням волокон, які пов'язують вестибулярні ядра довгастого мозку з медіанною ділянкою мозочка, ядрами окорухового нерва, таламусом і вестибулярними ділянками кори. В одних випадках запаморочення може бути наслідком ураження центральних вестибулярних структур, в інших - поєднується з ураженням інфратенторіальних ділянок. Центральне вестибулярне запаморочення розвивається або ізольовано, або у складі складних стовбурових або мозочкових синдромів і поєднується з різними окоруховими розладами, порушенням сприйняття та рівноваги.

Причина центрального вестибулярного запаморочення ураження провідникових шляхів між вестибулярними ядрами довгастого мозку і окоруховими ядрами, краніальною ділянкою середнього мозку, медіальною ділянкою мозочка, таламуса і вестибулярними ділянками кори в скронево-тім'яній ділянці. Тобто центральне вестибулярне запаморочення перш за все зумовлено ураженням шляхів, що забезпечують вестибулярний рефлекс. Вони можуть виникати при ішемічному інсульті, крововиливах, пухлинах, демієлінізації, вестибулярній епілепсії.

\section{Ішемія чи інфаркт стовбура мозку}

Ішемія у вертебрально-базилярному басейні зазвичай супроводжується запамороченням. Крім того, можливі транзиторна незграбність рухів, слабкість, порушення зору, двоїння в очах, гіпестезія у періорбітальній ділянці, атаксія, дизартрія і дроп-атаки (напади атонії в ногах і падіння).

Надання допомоги:

- виключити всі фактори ризику, які могли призвести до транзиторної ішемічної атаки у вертебрально-базилярній системі (артеріальна гіпертензія, гіперліпідемія, цукровий діабет, куріння, алкоголь, нестабільність у шийному відділі хребта, патологія серця як фактор кардіоемболії);

- лікування, спрямоване на профілактику транзиторної ішемічної атаки чи гострого інсульту (основні препарати - антиагреганти, в тому числі ацетилсаліцилова кислота в дозі 100 мг 1 раз на добу);

- при підозрі на ішемію чи інфаркт стовбура мозку - стаціонарне лікування.

\section{Базилярна мігрень (мігрень базилярної артерії)}

Частіше це захворювання виявляють у жінок молодого віку. У них епізодично виникає дифузний пульсуючий головний біль, двоїння, дизартрія, запаморочення, атаксія, двобічне зниження зору. У $15 \%$ хворих на цьому тлі може виникати інфаркт стовбура мозку. Базилярна мігрень характеризується нападами запаморочення в поєднанні з різними стовбуровими симптомами зі статичною і динамічною атаксією, а також порушенням зору. Після нападу у хворих з'являється біль у потилиці та блювання.

Обов'язкові діагностичні критерії вестибулярної мігрені - збіг за часом розвитку вестибулярних симптомів, таких як вертиго і непереносимість при рухах головою, головний біль, фотофобії та фонофобії (симптоми мігрені).

Базилярну вестибулярну мігрень розглядають як тип мігрені з аурою. Для визначення мігрені мають бути такі критерії:

- як мінімум 5 епізодів вестибулярних порушень помірної чи інтенсивної вираженості тривалістю від 5 хв до 72 год;

- наявність мігрені на даний час або дані про мігрень з/без аури;

- один із декількохпроявів мігрені як мінімум і 50\% вестибулярних епізодів;

- однобічний пульсуючий головний біль;

- фотофобія, фонофобія;

- зорова аура;

- в основі вестибулярних порушень не лежить інше захворювання. Надання допомоги:

- обов'язкове обстеження;

- ерготамін, суматриптан, блокатори $\beta$-адренорецепторів, амітриптилін, метисергід.

Систематичне профілактичне лікування може знизити частоту епізодів захворювання.

\section{Епілепсія та запаморочення}

Ізольоване запаморочення не супроводжується втратою свідомості. Бувають епізоди запаморочення, які супроводжуються нападами епілепсії, втратою свідомості, але перед цим спостерігають рухи причмокування, жування чи рухову активність (парціальні напади), тобто можливі епізоди ізольованого запаморочення, до якого приєднується порушення свідомості. Прогноз залежить від патологічного процесу; він малопозитивний, особливо якщо напади спричинені пухлиною. Напади можуть провокуватися вживанням алкоголю чи недосипанням.

Надання допомоги:

- комплексне обстеження; 
- протисудомна терапія може повністю запобігти нападам

\section{Розсіяний склероз}

При розсіяному склерозі можуть виникати перехідні симптоми («миготіння»), тобто дисеміновані у часі. Так, при одному з епізодів загострення відзначають запаморочення, при наступному неврит зорового нерва. Клінічний діагноз підтверджується даними магнітно-резонансної томографії. Розсіяний склероз має тенденцію до прогресування з появою нових скарг і симптомів неврологічного характеру.

Надання допомоги:

- лікування, спрямоване на розсіяний склероз.

Профілактичних заходів немає.

\section{Мальформація Арнольда - Кіарі}

Патологія спричинена защемленням мозочка і стовбура мозку нижче рівня великого потиличного отвору. Стан зазвичай проявляється нестійкістю, запамороченням, ністагмом, часто направленим при погляді убік. Симптоми зазвичай прогресують із часом. Поступово виникає головний біль під час кашлю на фоні прогресуючої компресії стовбура мозку.

Надання допомоги:

- обстеження

- після верифікації діагнозу - хірургічне лікування, яке зменшує прогресування стовбурових симптомів, а інколи приводить до повного регресу клінічної симптоматики.

\section{Запаморочення внаслідок дії медикаментів та при інших системних захворюваннях \\ Постуральна гіпотензія}

Постуральна (ортостатична) гіпотензія може проявлятися відчуттям нестійкості, але не руху предметів. Інколи напади несистемного запаморочення можуть проявлятися при зміні положення тіла (при вставанні) і супроводжуватися потемнінням в очах. Постуральна гіпотензія можлива при довготривалому стоянні, як вегетативна нейропатія (при цукровому діабеті), при застосуванні окремих препаратів (в тому числі антигіпертензивних).

Запаморочення може виникати при застосуванні протисудомних, снодійних препаратів, транквілізаторів. Вони викликають зниження артеріального тиску, запаморочення, відчуття «пустоти в голові», нестійкість, порушення координації. Симптоми зникають при коректній поступовій відміні цих препаратів.

У людей старшого віку може бути поєднання декількох типів сенсорного дефекту - множинна еферентна втрата чутливості яка проявляється втратою (погіршенням) слуху, зору, вестибулярним запамороченням, периферичною нейропатією. Ці ураження призводять до нестійкості при стоянні та ході, падіння хворих, що вказує на те, що всі сенсорні системи беруть участь у забезпеченні відчуття стійкості та підтриманні рівноваги. Прогноз ви- значають можливістю зворотного процесу або корекції, особливо зору, слуху

Невідкладна допомога:

- вимірювання артеріального тиску, при різкому зниженні кофеїн, гідрокортизон (флудрокортизон);

- хворі підлягають комплексному обстеженню.

Прогноз залежить від патології, яка призвела до гіпотензії.

\section{Запаморочення при порушенні ритму серця}

За наявності синкопальних або гіпотимічних станів із запамороченням внаслідок порушення ритму серця пацієнта потрібно терміново обстежити, оскільки існує ризик розвитку асистолії. Хворим призначають протиаритмічні засоби, імплантують кардіостимулятор.

Запаморочення може виникати при метаболічнихпорушеннях, включаючи гіпоглікемію, гіпотиреоз. Пацієнти скаржаться на відчуття нестійкості, несистемні запаморочення, слабкість. Це може відбуватися при епізодичній гіпоглікемії, яка коригується адекватною терапією. Корекція метаболічних порушень зазвичай зменшує вираженість запаморочення, при правильному лікуванні зумовлює повне зникнення симптомів.

\section{Психогенне запаморочення}

Психогенне запаморочення не відповідає жодному з відомих захворювань вестибулярної системи, супроводжується тривогою, депресією, дисоціативними та соматоформними розладами. Приклад психогенного запаморочення - фобічне постуральне запаморочення у людей з елементами нав'язливості, нападами нестійкості, що провокуються певними обставинами чи виникають спонтанно. У пацієнтів змінений стан особистості, вони пред'являють до себе підвищені вимоги, вкрай подразливі, вразливі.

Надання допомоги:

- комплексне обстеження для виключення органічних змін у нервовій системі, з боку серця, порушень психіки;

- інгібітори зворотного захоплення серотоніну (пароксетин 10-40 мг/добу, три- або тетрациклічні антидепресанти протягом 3-6 міс);

- рекомендовані заняття спортом, загартування.

\section{Висновки}

Таким чином, запаморочення відзначають не лише в неврологічній та оториноларингологічній практиці. Запаморочення не нозологічна форма, а група синдромів з різними проявами та етіологією.

\section{Список рекомендованої літератури}

Мищенко Т.С., Мищенко В.Н. (2018) Неврология в вопросах и ответах. Киев, Здоровье Украины, 340 с.

Труст Б.Т., Валер М.А. (2015) Головокружение. Хосе Биллер, Практическая неврология. Медицинская литература, Москва, 297-314 с.

\section{1. Як класифікують запаморочення?}

- периферичне вестибулярне

- центральне вестибулярне

- змішане

\section{2. Як діагностують запаморочення?}

- дослідження статичної та динамічної рівноваги, окорухових нервів, вестибулярний ністагм

- імунологічні проби

- комп'ютерна томографія, магнітно-резонансна томографія, ультразвукова допплерографія, рентгенографія шийного відділу хребта

\section{3. Які основні клінічні прояви доброякісного позиційного запаморочення?}

- запаморочення

- горизонтальний ротаторний ністагм
- порушення сечовиділення

- блювання

\section{4. Що таке вестибулярний нейроніт} (вестибулопатія)?

- ураження мозочка

- запаморочення, пов'язане з вірусним запаленням присінковозавиткового нерва

- стійке системне запаморочення зі спонтанним горизонтальноротаторним ністагмом

\section{5. Хвороба Мен'єра:}

- супроводжується когнітивними порушеннями

- виникає внаслідок ендолімфатичної водянки, розриву стінки перетинчастого лабіринту

- характеризується нападами вестибулярних і слухових порушень, поступовим зниженням слуху, шумом у вусі 


\section{6. При вестибулярній пароксизмії:}

- спостерігають короткочасні напади запаморочення, пов'язані зі здавленням нерва судиною, що призводить до демієлінізації

- наявна гіперактивність у ядрах присінково-завиткового нерва

- наявна мальформація чи аневризма артерій задньої черепної ямки

- наявні центральні і окорухові розлади

- напади виникають при зміні положення голови, гіпервентиляції

\section{7. Двобічна вестибулопатія - це:}

- патологія лабіринту, присінково-завиткового нерва

- порушення пам'яті

- стан, спричинений порушенням вестибулоокулярного і вестибулоспінального рефлексів, токсичним впливом лікарських засобів

- стан, що проявляється осцилопією, нечіткістю зору, нестійкістю при ходьбі, особливо в темряв

\section{8. Центральне вестибулярне запаморочення:}

- пов'язане зі стовбуровою та мозочковою патологією

- це ураження провідних шляхів між вестибулярними ядрами довгастого мозку і окоруховими ядрами, краніальною ділянкою середнього мозку, вестибулярною ділянкою кори у скронево-тім'яній ділянці

- може виникати при абдомінальній патології

- може бути спричинене інсультом, пухлиною, ділянкою демієлінізації, вестибулярною епілепсією

- проявляється спонтанним або позиційним запамороченням у поєднанні з симптомами ураження стовбура мозку, мозочка, кори

\section{9. При базилярній вестибулярній мігрені:}

- фактором ризику є спадковість

- наявна активація дорзальних ядер шва стовбура мозку (мосту з голубуватим місцем)

- спостерігають напади запаморочення з різними стовбуровими симптомами зі статичною та динамічною атаксією, розладами зору

\section{0. Психогенне запаморочення:}

- відзначають у емоційних осіб, при фобіях, депресії
- супроводжується запамороченням і розладами рівноваги, ознак ураження вестибулярного апарату немає

- напади провокуються окремими обставинами, інколи спонтанно, часто наявна тривога

- показані тетрациклічні антидепресанти, психотерапія, заняття спортом

\section{1. Пухлина мосто-мозочкового кута (VIII пара черепно-мозкових нервів - невринома):}

- походить із вестибулярної порції нерва в слуховому (фаллопієвому) каналі

- уражається слуховий, лицевий, трійчастий нерви, інколи стовбур мозку та мозочок

- можлива втрата мови

- нестійке запаморочення, порушення рівноваги, можливі втрата слуху, ураження лицевого нерва

\section{2. При ішемії або інфаркті стовбура мозку (вертебробазилярній недостатності) відзначають:}

- минущу незграбність рухів, слабкість

- порушення зору (двоїння)

- атаксію

- дизартрію

\section{3. При мальформації Арнольда - Кіарі:}

- відзначають переміжну кульгавість

- наявне защемлення мозочка і стовбура мозку нижче рівня великого потиличного отвору

- відзначають запаморочення, ністагм

- з часом з'являється головний біль, особливо при кашлі, стовбурові симптоми

\section{4. Постуральна (ортостатична) гіпотензія:}

- може проявлятися відчуттям нестійкості (але не руху предметів), підсилюючись при зміні положення тіла

- можлива при передозуванні антибіотиків

- може проявлятися потемнінням в очах, непритомністю

- можлива при передозуванні антигіпертензивних препаратів

Для отримання сертифіката дайте відповідь на тестові запитання в режимі on-line на сайті журналу www.umj.com.ua або надішліть ксерокопію сторінок з відповідями разом з контактною інформацією за адресою: 01001, Київ-1, a/c «В»-82, ТОВ «МОРІОН»

\section{КОНТАКТНІ ДАНІ:}

ПІБ

Поштова адреса: індекс

область

район

місто

вулиця

будинок

квартира

Телефон

E-mail 